\title{
Cessation of dangerousness status: an analysis of 224 reports from the Instituto de Perícias Heitor Carrilho, Rio de Janeiro, Brazil
}

\author{
Gustavo C. Oliveira, ${ }^{1,2}$ Alexandre M. Valença, ${ }^{2,3}$ Talvane M. de Moraes, ${ }^{2}$ Mauro V. Mendlowicz, ${ }^{3}$ \\ Miles C. Forrest, ${ }^{4}$ Fred F. Batista, ${ }^{5}$ Gabriella A. Mendes, ${ }^{5}$ Tiago N. Lima, ${ }^{5}$ Vinicius R. Gonçalves, ${ }^{5}$ \\ Kátia Mecler ${ }^{2}$ \\ ${ }^{1}$ Unidade de Psiquiatria, Hospital de Base do Distrito Federal, Brasília, DF, Brazil. ${ }^{2}$ Instituto de Psiquiatria, Universidade Federal do Rio de \\ Janeiro (UFRJ), Rio de Janeiro, RJ, Brazil. ${ }^{3}$ Departamento de Psiquiatria e Saúde Mental, Universidade Federal Fluminense (UFF), Niterói, RJ, \\ Brazil. ${ }^{4}$ Departamento de Psiquiatria, Instituto de Saúde Mental (ISM), Brasília, DF, Brazil. ${ }^{5}$ UFRJ, Rio de Janeiro, RJ, Brazil.
}

\begin{abstract}
Objectives: To evaluate factors related to dangerousness cessation at the end of involuntary commitment based on an analysis of expert reports. In light of the current legal requirement of dangerousness cessation as a pre-requisite for prison or internment release of individuals subjected to the safety measure, we sought elements to reflect on the practice of expert examiners in charge of making this decision.

Methods: The authors revised 224 expert psychiatric dangerousness cessation reports released 2011 through 2014 and collected data for a statistical analysis.

Results: The following variables were associated with positive risk cessation assessments: no inadequate behavior (according to the assistant professionals), no productive psychotic symptoms, no negative symptoms, presence of insight, presence of a support network, and no psychoactive substance abuse. The following variables were associated with negative dangerousness cessation decisions: early onset of malfunction, lack of insight, negative attitudes, active signs of major mental illness, presence of impulsiveness, poor response to treatment, presence of plans lacking feasibility, exposure to destabilizing factors, lack of personal support, and presence of stress.

Conclusions: In this study we were able to identify factors associated with dangerousness in a sample of expert reports. The knowledge of factors linked to a higher risk of recidivism in illegal activities or violent behavior is crucial for decision-making regarding the release of offenders after their legally established period of involuntary commitment.
\end{abstract}

Keywords: Forensic psychiatry; commitment of the mentally ill; insanity defense; mental disorders; violence

\section{Introduction}

The concept of criminal dangerousness first appeared in Brazil towards the end of the 19th century with the positive school of penal law, and became a central paradigm of modern penal law. As opposed to classical law, which focuses on the severity of criminal offenses and determines punishments accordingly, positive law interprets an offense as a symptom of dangerousness, as a revealing indicator of criminal personality. ${ }^{1,2}$

In the context of the positive school, a criminal is not a rational being who acts of free will. A delinquent person is considered to belong to a special class, of those affected by psychosomatic abnormalities. ${ }^{1,3}$ The purpose of science is to discover the causes that lead up to crime. This is not a mere moral issue, but rather a broad concept that involves medicine, psychology, and sociology.,

Correspondence: Gustavo C. Oliveira, Unidade de Psiquiatria, Hospital de Base do Distrito Federal, Quadra 101, Bloco B - Área Especial, CEP 71330-150, Brasília, DF, Brazil.

E-mail: psiquiatragustavo@gmail.com

Submitted Nov 28 2015, accepted Mar 082016.
Thus it is clear that sentences must be adjusted to the characteristics of offenders, in consonance with the principle of social defense - according to which it is justifiable that society should protect dangerous individuals. Special sentencing for the mentally ill was termed "safety measure" in Brazil, because it provided such protection. It should be applied and maintained until the individuals' dangerousness has subsided, or "ceased."1,3

The first author to attempt a classification of the legal concept of dangerousness was Raffaele Garófalo, in 1878. ${ }^{1,4}$ He proposed that sanctions should be applied as a means to prevent crime, and that they should not be determined solely based on the severity of a crime or the failure to fulfill a duty, but also on the "fearfulness" of the offender. He defined frightfulness as "the constant and active perversity of the offender and the amount of harm that should be expected and that should be feared" (Garófalo 1878 apud Mecler, ${ }^{1}$ p. 71). ${ }^{4}$

Based on this key concept, when the International Union of Penal Law (UIDP, currently International Association of Penal Law) was founded, in 1889, debate and research were focused on various possible criteria for classifying degree of risk. ${ }^{1,2}$ In the 1913 UIDP International 
Congress, three categories of dangerous individuals were created: recidivists; alcoholics and the handicapped of any kind; and hobos and beggars. ${ }^{1,2}$

In 1920, Ásua proposed the following traits as factors by which to determine dangerousness: "a man's personality, in its three facets: anthropological, psychical, and moral; the life history prior to the offense; the offender's behavior after the crime; the quality of the motives; and the crime itself" (Ásua 1920 apud Mecler, ${ }^{1}$ p. 71). ${ }^{2}$

Loudet, in $1939^{5}$ considered that determining dangerousness status was tantamount to exercising preventive medicine, since carrying out protective and tutelary actions before the occurrence of an anti-social reaction would be the basis for the effective protection of society. Along these lines, he created the following indexing categories of dangerousness:

a) Medico-psychological: those that are caused by the existence of mental states of alienation or of semi-alienation, or by plain psychical imbalances with or without accompanying somatic disorders, by which, under certain or uncertain circumstances, we are able to prognosticate an antisocial reaction in a given subject.

b) Social: they are determined by external factors. In this case, dangerousness is not in the subjects, but in the environment, which nurtures them, stimulates them, excites them. With the suppression of this stimulus, this nurturing, this excitement, dangerousness disappears. Among the social causes, according to the author, the financial ones would be the most important.

c) Legal: those related to the subject's criminal background and to the offense. Loudet considered the legal indices to be of lesser importance. For him, they could only add ancillary elements, and furthermore were often subordinated to the medico-psychological and social indices.

The idea of dangerousness was incorporated into Brazilian legislation in 1940. The new Brazilian Penal Code contained the double/binary system, which created two quite different outcomes for chargeable individuals ${ }^{1,2}$ : 1) a penalizing sentence, of a punitive nature, based on a subject's accountability and on the severity of the offense; and 2) the safety measure, of a preventive nature, for which the dangerousness of the accused is taken into account and which entails involuntary commitment. ${ }^{1,2}$ The purpose of the safety measure was to ensure protection to society and proper treatment for the subject, aiming to reduce his or her dangerousness. ${ }^{3}$

This concept concurs with the ideas of forensic psychiatrist Heitor Carrilho, set forth decades earlier, that forensic psychiatry should not be limited to determining whether an individual is mentally developed. The state of dangerousness and subsequent frightfulness of delinquents, examined according to precise anthropological and psychological standards, shall be the basis for all repressive legislation. ${ }^{6,7}$

The 1984 Penal Code revision put an end to the double binary system, and the safety measure was no longer imposed on chargeable delinquents, ${ }^{8}$ but limited to the nonchargeable individuals (e.g., a person with no sign of mental illness can no longer be subjected to a safety measure). In 2001, Moraes ${ }^{9}$ noted that the widespread use of the presumed dangerousness concept and the resulting safety measure applied only to the nonchargeable was perpetuating the notion that the mentally ill are necessarily dangerous.

According to the current Brazilian legislation, the safety measure may be applied in the form of commitment to a custody hospital and psychiatric treatment (Penal Code, art. 96, I) or in the form of outpatient treatment (Penal Code, art. 96, II). Dangerousness cessation must be determined by an official psychiatric examiner who produces an expert medical report determining whether or not dangerousness has ceased (the "dangerousness cessation report"). Though there are no pre-established time frames for involuntary commitments under the safety measure, judges will stipulate a minimum duration of 1 to 3 years. The cessation examination must be carried out at the end of the stipulated time, and will be repeated yearly as long as dangerousness cessation has not been established. In this context, dangerousness is a legal, not medical, concept, and it is assumed that the examiner is able to foresee the future behavior of these individuals. ${ }^{1,2}$

Standardized risk assessment instruments have been developed over the past few decades in order to systematize risk of violence prediction in a more objective manner. The widespread use of these tools, in both clinical practice and the forensic field, should provide additional elements for dangerousness assessment and greater reliability to determine the probability of individuals committing violent acts. This should consequently lead to a lower level of criminal recidivism. The Psychopathy Checklist - Revised (PCL-R), ${ }^{10}$ the Barrat Impulsiveness Scale (BIS-11), ${ }^{11}$ and the Historical, Clinical and Risk Management Violence Risk Assessment Scheme (HCR-20) ${ }^{12}$ are among the most widely employed.

The PCL-R is a scale that covers behavior, emotional traits, and clinical psychopathic characteristics, designed to measure degrees of psychopathy. ${ }^{10}$ The BIS-11 is a self-report scale. It measures impulsiveness by assessment of three main areas: motor, cognitive, and lack of planning, according to the chart. ${ }^{11}$ The HCR-20 is intended to assess the risk of future violent behavior in offenders with mental illness. It includes 20 items that cover historic and clinical aspects as well as risk management, for which reason it is more appropriate to assess dangerousness cessation. ${ }^{12}$

The objective of this study was to evaluate factors related to dangerousness cessation at the end of involuntary commitment based on an analysis of expert reports. In light of the current legal requirement of dangerousness cessation as a pre-requisite for prison or internment release of individuals subjected to the safety measure, we seek elements to reflect on the practice of expert examiners in charge of making this decision.

\section{Methods}

This cross-sectional study used retrospective data extracted from all the dangerousness cessation reports issued over a period of 4 years by Instituto de Perícias Heitor Carrilho, state of Rio de Janeiro, Brazil. This is the only institution in the state of Rio de Janeiro to issue a dangerousness 
cessation report (Exame de Verificação da Cessação da Periculosidade - EVCP). We studied the records of offenders who were found not guilty by reason of insanity by the criminal courts of the state of Rio de Janeiro and were committed to the Institute for a minimum of 1 year after being subjected to the safety measure in prison hospitals in the State of Rio de Janeiro. The experts were experienced State-appointed professional forensic experts using the ICD-10. Two-hundred and twenty-four EVCP reports issued from 2011 to 2014 were obtained from the forensic hospital archives for data collection.

Data were collected by forensic and clinical psychiatrists and last-year medical students at the Universidade Federal do Rio de Janeiro (UFRJ). The students were trained and used a standardized questionnaire elaborated by the authors for data collection. Questionnaire data were reviewed by one or more forensic psychiatrists prior to analysis.

Preliminary examination of the EVCP reports revealed that the fields available for a detailed descriptive annotation of the examination process in most cases contained only summary information. Thus, we classified as "maybe" all information contained in the report that was not conclusive regarding the variable being analyzed, or assessments described as possible, probable, unlikely, and so forth, by the forensic psychiatrist.

The following variables were studied: sociodemographic variables (gender, age, ethnicity, marital status, education, profession, socioeconomic level, family support), psychiatric diagnosis, offense (as coded in the Brazilian Penal Code), conclusions of the reports (dangerousness "ceased" or "not ceased"), presence or absence of productive symptoms, degree of insight, presence or absence of negative symptoms, presence or absence of previous failures in treatment as reported by assistant health professionals, support provided by the health system, subjects' compliance with treatment, concomitant substance abuse, and psychiatric and drug addiction backgrounds.

The findings were grouped based on a criterion of similarity among reports and classified according to a modified version of the Mecler classification. This classification was created in a pioneering study by Mecler ${ }^{2}$ in 1996, in which dangerousness cessation reports were analyzed. By means of a qualitative study of the reports, Mecler assessed which criteria were the most commonly associated with dangerousness cessation and used this information to elaborate a scale. After determining the relevance and the applicability of the criteria thus obtained, Mecler $^{2}$ created a classification of items according to active productive symptoms, insight, negative symptoms, prior supervision failure, inadequate behavior at the institution, opinion expressed by healthcare assistant staff, compliance with treatment, substance abuse, and history of drug addiction or psychiatric treatment.

\section{Statistical analysis}

Data were imported into Microsoft Excel (2013 version) and analyzed using Epi-Info version 7 and SPSS version $20 .^{13}$
The results are presented as percentages and $95 \%$ confidence intervals $(95 \% \mathrm{Cl})$.

Association between all independent variables and dangerousness cessation - the dependent variable - were analyzed using the chi-square test. ${ }^{14,15}$ Statistical significance was assessed using the bilateral test, with a $p=0.05$. The odds ratio of each factor being associated with cessation or non-cessation was calculated to determine which sociodemographic HCR-20 and Mecler variables were important for the decision of "dangerousness cessation."

The project was approved by the Ethics Committee at Instituto de Psiquiatria - Universidade Federal do Rio de Janeiro (IPUB-UFRJ), registered as CAAE 50045115. 4.0000.5263, evaluation number 1.338.496. The need for free and informed consent was waived given the secondary nature of the data.

\section{Results}

Of the 224 cases analyzed, $85.98 \%$ reported positive dangerousness cessation assessment. Most of the 224 subjects were male (93.3\%). Roughly half were in the 35 to 50-year age group. Considering the whole sample $(n=224)$, level of education was distributed as no schooling in $50.8 \%$, some level of education in $20.5 \%$, and unknown in $28.7 \%$. Conversely, when only the subjects who provided this information were considered, the results were $71.3 \%$ of illiterate and $28.7 \%$ of literate patients (Table 1). Most individuals were unskilled workers; only $24.9 \%$ had a profession. Only $9.8 \%$ were married; $61.2 \%$ were single, and $29 \%$ were divorced or widowed.

The most common crimes were homicide (33.8\%) and robbery $(21.7 \%)$, coded as articles 121 and 157 respectively in the Brazilian Penal Code. The most common psychiatric diagnosis was schizophrenia (including schizophrenia subtypes), reported in $42.9 \%$ of cases in which a diagnosis was informed, followed by intellectual disability (including all degrees of intellectual disability reported) (12.9\%), drug-induced psychosis (9.6\%), bipolar disorder (5\%), and personality disorder (5\%).

The subjects' social and family situation was a particularly common item cited as a reason for dangerousness cessation. Social services classify individuals into three groups: with family, without family, and with family but without support. "With family but without support" refers to situations in which the family shows no interest in the subject, and typically does not desire for him or her to come back home.

The socioeconomic level of the examinees was determined by their income, which was low overall: $58.8 \%$ earned up to half of minimum wage, $26.5 \%$ earned between half and 2 minimum wages, and $14.7 \%$ had some form of welfare support, which was in no case higher than one minimum wage.

The only sociodemographic variable that was statistically associated with dangerousness cessation was presence of family support. Individuals who had support from their families were more likely to be considered not dangerous. 
Table 1 Distribution of individuals evaluated for dangerousness cessation according to sociodemographic variables $(n=224)$

\begin{tabular}{|c|c|c|}
\hline Variable & $\mathrm{n}(\%)$ & $95 \% \mathrm{Cl}$ \\
\hline \multicolumn{3}{|l|}{ Gender } \\
\hline Male & $209(93.3)$ & $90.6-96.0$ \\
\hline Female & $15(6.7)$ & $4.0-9.4$ \\
\hline Total & 224 & \\
\hline \multicolumn{3}{|l|}{ Age (years) } \\
\hline $20-30$ & $46(20.7)$ & $16.2-25.2$ \\
\hline $31-40$ & 85 (38.3) & $32.9-43.7$ \\
\hline $41-50$ & $43(19.4)$ & $15.0-23.8$ \\
\hline $51-60$ & $36(16.2)$ & 12.1-20.3 \\
\hline$>60$ & $12(5.4)$ & 2.9-7.9 \\
\hline Total & 222 & \\
\hline \multicolumn{3}{|l|}{ Marital status } \\
\hline Single & $137(61.2)$ & $55.8-66.6$ \\
\hline Married & $22(9.8)$ & $6.5-13.1$ \\
\hline Widowed or divorced & $65(29)$ & $24.0-34.0$ \\
\hline Total & 224 & \\
\hline \multicolumn{3}{|l|}{ Education } \\
\hline No schooling (illiterate) & $129(71.3)$ & $65.8-76.8$ \\
\hline With schooling (literate) & $52(28.7)$ & $23.2-34.2$ \\
\hline Total & 181 & \\
\hline \multicolumn{3}{|l|}{ Profession } \\
\hline Skilled & $45(24.9)$ & $19.6-30.2$ \\
\hline Unskilled & $136(75.1)$ & $69.8-80.4$ \\
\hline Total & 181 & \\
\hline \multicolumn{3}{|l|}{ Socioeconomic level } \\
\hline Up to half minimum wage & $20(58.8)$ & $40.7-75.4$ \\
\hline Half to 2 minimum wages & $9(26.5)$ & 12.9-44.4 \\
\hline Welfare support & $5(14.7)$ & 4.9-31.1 \\
\hline Total & 34 & \\
\hline \multicolumn{3}{|l|}{ Family support } \\
\hline With family and with support & $153(76.1)$ & $71.2-81.0$ \\
\hline With family and without support & $23(11.4)$ & 7.7-15.1 \\
\hline Without family, without support & $25(12.4)$ & 8.6-16.2 \\
\hline Total & 201 & \\
\hline
\end{tabular}

$95 \% \mathrm{Cl}=95 \%$ confidence interval.

Table 1 and Table 2 show the sociodemographic profile of individuals evaluated for dangerousness cessation. In all tables, missing data reflect lacking or inconclusive information in the reports.

The following items were statistically associated with a positive dangerousness cessation report:

- Mecler criteria: items according to the healthcare assistant staff, absence of productive symptoms (delusions and hallucinations), absence of negative symptoms, existence of insight, existence of support from the assistance network, and absence of psychoactive drug addiction.

- HCR-20: early-onset maladjustment (items related to personal history/background); lack of insight, negative attitudes, active signs of major mental illness, impulsiveness, and a poor or absent response to treatment (clinical items); plans lacking feasibility, exposure to destabilizing factors, lack of support, and the presence of stress (riskmanagement items).
Statistical tests were run to correlate dangerousness cessation with diagnosed disorders and with the type of crime stated in the reports; the results showed no statistical significance. This analysis was limited by the large number of reports without information about diagnosis and/or offense. The lack of specific data on treatment, such as the period of safety measure or medication prescribed, made it impossible to analyze in detail the therapeutic value of the safety measure. Table 3 and Table 4 show these results.

\section{Discussion}

A noteworthy majority of the individuals assessed by the examiners were deemed not dangerous ( $85.98 \%)$. This is an important finding, given the technical team's efforts to provide multidisciplinary treatment focusing on the subjects' release. In the study conducted by Mecler in 1996, ${ }^{1}$ dangerousness was considered to have ceased in 56.3\% of the reports. The evolution of medicine - and of psychiatry in particular - and the appearance of new psychotropic drugs may explain why the results were so different, 20 years later, at the same institution. Major changes in the current mental health policy, which favors community and outpatient treatment, are also likely to have contributed to this difference.

The purpose of the safety measure is twofold: to protect society from the possible violent behavior of psychiatric patients who have committed crimes, and to assist in the recovery of these patients - who are the chief victims of the consequences of their malady. ${ }^{16,17}$ In ethical terms, there are no cut-and-dried guidelines for the procedure conducted by forensic psychiatrists in order to issue a dangerousness cessation report. ${ }^{18,19}$ This could explain the fact that the study revealed an overall lack of standardization and systematization in risk assessment.

The severity of an offense, the criminal history, and the psychiatric history of a subject, all of which have been considered as criteria of great importance in studies over the past few years, ${ }^{20-30}$ were quite undervalued in the dangerousness cessation reports we studied. The reports seem to have been made in a manner reminiscent of the model used by Loudet in the 1930s, emphasizing the medico-psychological and social indices as the most important elements in risk assessment. ${ }^{2,5}$

Other criteria that were found to be lacking, shown as important by recent research, are historical variables (psychiatric and criminal) and the examination of subjects by forensic experts, specifically concerning the severity and typicality of the crimes. ${ }^{20-30}$ Several studies discuss that subject as regards the use of the HCR-20, worldwide $^{20,31}$ and specifically in Brazil. ${ }^{32}$ To not take into account such information may reduce the quality of a report, inasmuch as factors that are apt to be associated with an increased risk of recidivism could be overlooked. On the other hand, the experts responsible for the reports may have taken these factors into consideration, while failing to write about them.

In the present study, several HCR-20 criteria were statistically associated with both for dangerousness 
Table 2 Distribution of positive dangerousness cessation reports according to sociodemographic variables ( $\mathrm{n}=224)$

\begin{tabular}{|c|c|c|c|c|}
\hline \multirow[b]{2}{*}{ Variable } & \multirow[b]{2}{*}{ Total } & \multicolumn{2}{|c|}{ Dangerousness cessation } & \multirow[b]{2}{*}{$\mathrm{p}$-value } \\
\hline & & $\mathrm{n}(\%)$ & $95 \% \mathrm{Cl}$ & \\
\hline \multicolumn{5}{|l|}{ Gender } \\
\hline Male & 200 & $173(86.5)$ & $82.7-90.3$ & 0.409 \\
\hline Female & 14 & $11(78.6)$ & $74.0-83.2$ & \\
\hline $\mathrm{n}$ & 214 & $184(86.0)$ & $82.1-89.9$ & \\
\hline \multicolumn{5}{|l|}{ Age (years) } \\
\hline $20-30$ & 44 & $37(84.1)$ & $80.0-88.2$ & 0.481 \\
\hline $31-40$ & 82 & 72 (87.8) & $84.1-91.5$ & \\
\hline $41-50$ & 40 & $32(80)$ & $75.5-84.5$ & \\
\hline $51-60$ & 36 & $32(88.9)$ & 85.4-92.4 & \\
\hline$>60$ & 10 & $10(100)$ & $100.0-100.0$ & \\
\hline $\mathrm{n}$ & 212 & $183(86.3)$ & $82.4-90.2$ & \\
\hline \multicolumn{5}{|l|}{ Marital status } \\
\hline Single & 132 & $111(84.1)$ & $80.0-88.2$ & 0.574 \\
\hline Married & 22 & $20(90.9)$ & 87.7-94.1 & \\
\hline Widowed or divorced & 60 & 53 (88.3) & 84.7-91.9 & \\
\hline $\mathrm{n}$ & 214 & $184(86.0)$ & 82.1-89.9 & \\
\hline \multicolumn{5}{|l|}{ Education } \\
\hline No schooling & 125 & $106(84.8)$ & $80.3-89.3$ & 0.114 \\
\hline With schooling & 48 & 45 (93.8) & $90.8-96.8$ & \\
\hline $\mathrm{n}$ & 173 & $151(87.3)$ & $83.1-91.4$ & \\
\hline \multicolumn{5}{|l|}{ Profession } \\
\hline Skilled & 43 & $39(90.7)$ & 87.1-94.3 & 0.583 \\
\hline Unskilled & 129 & $113(87.6)$ & 83.5-91.7 & \\
\hline $\mathrm{n}$ & 172 & $152(88.4)$ & $84.4-92.4$ & \\
\hline \multicolumn{5}{|l|}{ Socioeconomic level } \\
\hline Up to half minimum wage & 20 & $15(75.0)$ & $59.1-90.9$ & 0.353 \\
\hline Half to 2 minimum wages & 9 & $8(88.9)$ & 71.7-106.1 & \\
\hline Welfare support & 5 & $5(100.0)$ & $100.0-100.0$ & \\
\hline$n$ & 34 & & & \\
\hline \multicolumn{5}{|l|}{ Family support } \\
\hline With family support & 149 & $135(90.6)$ & $87.1-94.1$ & 0.001 \\
\hline Without family support & 43 & $30(69.8)$ & 64.3-75.3 & \\
\hline $\mathrm{n}$ & 192 & $165(85.9)$ & $81.8-90.1$ & \\
\hline
\end{tabular}

$95 \% \mathrm{Cl}=95 \%$ confidence interval.

cessation and non-cessation. The items that stood out were clinical (lack of insight, negative attitudes, signs of active mental illness, and unresponsiveness to treatment), behavioral (impulsiveness, plans that lack feasibility), and social (exposure to destabilizing factors, lack of personal support, and presence of stress).

Studies conducted by Valença et al. ${ }^{22,33,34}$ focused on the relationship between sets of factors and violent behavior. Their findings concur with ours in that there is an important relationship between clinical factors and violent behavior, especially the following: presence of productive symptoms, relapses, lack of insight, and cognitive distortions. This shows the importance of adequate clinical management, not only to preserve the health of individual patients but also, as a consequence, to avoid criminal recidivism in the mentally ill.

Impulsive behavior and anger management issues, as well as a lack of social abilities, were also cited as important factors by Valença et al. ${ }^{22,33,34}$ This is in agreement with our findings, particularly in regard to the risk of new violent behavior, and might warrant the adoption of widespread strategies to reduce this risk factor. Social and environmental factors were also found to have a strong correlation, particularly drug addiction, a personal history of abuse, and lack of family support. In the case of individuals with mental disorders, the risk of violence associated with social and environmental aspects may be aggravated by vulnerabilities such as deficient psychical and cognitive resources to deal with situations that cannot be controlled. These data corroborate previous findings. ${ }^{20-22,24,26,30,33,34}$

Mecler ${ }^{1,2}$ found similar results in an analysis of dangerousness cessation examinations. As was the case in our study, that investigator found that important factors had been left out of a large number of dangerousness cessation reports, such as personal history and criminal background, as well as the nature of the offenses. This is all the more deserving of criticism when we consider the large number of studies showing the importance of these factors to assess risk of violence. ${ }^{20,23,24,26,29,30,34}$

Penal law in Brazil has evolved along the lines of what is termed the "pathologization" of criminal behavior, 
Table 3 Number and percentage of Mecler variables found in the positive dangerousness cessation reports

\begin{tabular}{|c|c|c|c|c|}
\hline \multirow[b]{2}{*}{ Variables } & \multirow[b]{2}{*}{ Total } & \multicolumn{2}{|c|}{ Dangerousness cessation } & \multirow[b]{2}{*}{$p$-value } \\
\hline & & n (\%) & $95 \% \mathrm{Cl}$ & \\
\hline \multicolumn{5}{|c|}{ Active productive symptoms } \\
\hline No & 159 & $150(94.3)$ & $91.3-97.3$ & $<0.001$ \\
\hline Maybe & 12 & $10(83.3)$ & $65.6-100.0$ & \\
\hline Yes & 36 & $17(47.2)$ & $33.5-60.9$ & \\
\hline Total & 207 & $177(85.5)$ & $81.5-89.5$ & \\
\hline \multicolumn{5}{|l|}{ Insight } \\
\hline No & 76 & $54(71.1)$ & $62.5-79.7$ & $<0.001$ \\
\hline Maybe & 12 & $10(83.3)$ & $65.6-100.0$ & \\
\hline Yes & 102 & $96(94.1)$ & $90.3-97.9$ & \\
\hline Total & 190 & $160(84.2)$ & $79.9-88.6$ & \\
\hline \multicolumn{5}{|c|}{ Negative symptoms } \\
\hline No & 159 & $144(90.6)$ & $86.8-94.4$ & 0.002 \\
\hline Maybe & 8 & 7 (87.5) & $68.3-100.0$ & \\
\hline Yes & 26 & $17(65.4)$ & $50.1-80.7$ & \\
\hline Total & 193 & $168(87.0)$ & $83.1-91.0$ & \\
\hline \multicolumn{5}{|c|}{ Prior supervision failure } \\
\hline No & 74 & $67(90.5)$ & $84.9-96.1$ & 0.116 \\
\hline Maybe & 14 & $12(85.7)$ & $70.3-100.0$ & \\
\hline Yes & 63 & $49(77.8)$ & $69.2-86.4$ & \\
\hline Total & 151 & $128(84.8)$ & $80.0-89.6$ & \\
\hline \multicolumn{5}{|c|}{ Inadequate behavior at the institution } \\
\hline No & 156 & $139(89.1)$ & 85.0-93.2 & 0.001 \\
\hline Maybe & 5 & $2(40)$ & $4.0-76.0$ & \\
\hline Yes & 8 & $5(62.5)$ & $34.3-90.7$ & \\
\hline Total & 169 & $146(86.4)$ & $82.1-90.7$ & \\
\hline \multicolumn{5}{|c|}{ Opinion expressed by assistant professionals } \\
\hline No & 23 & $12(52.2)$ & $35.1-69.3$ & $<0.001$ \\
\hline Maybe & 12 & $9(75)$ & $54.4-95.6$ & \\
\hline Yes & 160 & $147(91.9)$ & 88.4-95.4 & \\
\hline Total & 195 & $168(86.2)$ & 82.1-90.2 & \\
\hline \multicolumn{5}{|c|}{ Personal support } \\
\hline No & 7 & $3(42.9)$ & 12.1-73.7 & 0.001 \\
\hline Maybe & 14 & $12(85.7)$ & $70.3-100.0$ & \\
\hline Yes & 174 & $157(90.2)$ & 86.5-93.9 & \\
\hline Total & 195 & $172(88.2)$ & $84.4-92.0$ & \\
\hline \multicolumn{5}{|c|}{ Compliance with treatment } \\
\hline No & 7 & $6(85.7)$ & $63.9-100.0$ & 0.297 \\
\hline Maybe & 15 & $11(73.3)$ & $54.5-92.1$ & \\
\hline Yes & 178 & $156(87.6)$ & 83.5-91.7 & \\
\hline Total & 200 & $173(86.5)$ & $82.5-90.5$ & \\
\hline \multicolumn{5}{|c|}{ Substance abuse } \\
\hline No & 69 & $63(91.3)$ & $85.7-96.9$ & 0.015 \\
\hline Maybe & 6 & $3(50)$ & $16.4-83.6$ & \\
\hline Yes & 70 & $60(85.7)$ & 78.8-92.6 & \\
\hline Total & 145 & $126(86.9)$ & $82.3-91.5$ & \\
\hline \multicolumn{5}{|c|}{ Previous history (drug addiction or psychiatric treatment) } \\
\hline No & 40 & $36(90)$ & $82.2-97.8$ & 0.079 \\
\hline Maybe & 4 & $2(50)$ & $8.9-91.1$ & \\
\hline Yes & 122 & $106(86.9)$ & 81.9-91.9 & \\
\hline Total & 166 & $144(86.7)$ & $82.4-91.1$ & \\
\hline
\end{tabular}

$95 \% \mathrm{Cl}=95 \%$ confidence interval.

opposing the previously unbendable idea of free will. ${ }^{1}$ This bolstered current progress in the study and understanding of criminal acts as a medical phenomenon, which in turn facilitated the identification of associations between certain criminal behavior and mental illness. ${ }^{2,7,9}$
The judicial concept of dangerousness is currently viewed to have a scientific basis and is the subject of medicolegal research. ${ }^{2,9,19}$

Nonetheless, it is clearly difficult to conduct an adequate, comprehensive and reproducible assessment 
Table 4 Distribution of positive dangerousness cessation reports according to HCR2O criteria

\begin{tabular}{|c|c|c|c|c|}
\hline \multirow[b]{2}{*}{ Variables } & \multirow[b]{2}{*}{ Total } & \multicolumn{2}{|c|}{ Dangerousness cessation } & \multirow[b]{2}{*}{ p-value } \\
\hline & & n (\%) & $95 \% \mathrm{Cl}$ & \\
\hline \multicolumn{5}{|c|}{ Historical scale } \\
\hline \multicolumn{5}{|c|}{ Prior violence } \\
\hline No & 50 & $47(94)$ & 88.5-99.5 & \multirow[t]{4}{*}{0.124} \\
\hline Maybe & 1 & $1(100)$ & $100.0-100.0$ & \\
\hline Yes & 64 & $52(81.2)$ & $73.2-89.2$ & \\
\hline Total & 115 & $100(87.0)$ & $81.8-92.1$ & \\
\hline \multicolumn{5}{|c|}{ Young age at first violent incident } \\
\hline No & 50 & $47(94)$ & 88.5-99.5 & \multirow[t]{4}{*}{0.153} \\
\hline Maybe & 1 & $1(100)$ & $100.0-100.0$ & \\
\hline Yes & 55 & $45(81.8)$ & $73.2-90.4$ & \\
\hline Total & 106 & $93(87.7)$ & $82.5-93.0$ & \\
\hline \multicolumn{5}{|c|}{ Relationship instability } \\
\hline No & 43 & $40(93)$ & 86.6-99.4 & \multirow[t]{4}{*}{0.22} \\
\hline Maybe & 21 & $18(85.7)$ & $73.1-98.3$ & \\
\hline Yes & 23 & $18(78.3)$ & $64.2-92.4$ & \\
\hline Total & 87 & $76(87.4)$ & $81.5-93.2$ & \\
\hline \multicolumn{5}{|c|}{ Employment problems } \\
\hline No & 54 & $50(92.6)$ & $86.7-98.5$ & 0.262 \\
\hline Maybe & 11 & $9(81.8)$ & $62.7-100.0$ & \\
\hline Yes & 12 & $12(100)$ & $100.0-100.0$ & \\
\hline Total & 77 & $71(92.2)$ & 87.2-97.2 & \\
\hline Substance & & & & \\
\hline No & 38 & $32(84.2)$ & $74.5-93.9$ & 0.58 \\
\hline Maybe & 4 & $4(100)$ & $100.0-100.0$ & \\
\hline Yes & 89 & $79(88.8)$ & 83.3-94.3 & \\
\hline Total & 131 & $115(87.8)$ & $83.1-92.5$ & \\
\hline Major mel & & & & \\
\hline No & 67 & $60(89.6)$ & $83.5-95.7$ & 0.367 \\
\hline Maybe & 3 & $3(100)$ & $100.0-100.0$ & \\
\hline Yes & 105 & 87 (82.9) & $76.9-88.9$ & \\
\hline Total & 175 & $150(85.7)$ & $81.4-90.1$ & \\
\hline Psychopa & & & & \\
\hline No & 126 & $109(86.5)$ & $81.5-91.5$ & 0.677 \\
\hline Maybe & 5 & $5(100)$ & $100.0-100.0$ & \\
\hline Yes & 16 & $14(87.5)$ & $73.9-100.0$ & \\
\hline Total & 147 & $128(87.1)$ & $82.5-91.6$ & \\
\hline Early mal & & & & \\
\hline No & 76 & $69(90.8)$ & 85.3-96.3 & 0.042 \\
\hline Maybe & 14 & $13(92.9)$ & $81.6-100.0$ & \\
\hline Yes & 44 & $33(75)$ & 64.3-85.7 & \\
\hline Total & 134 & $115(85.8)$ & $80.9-90.8$ & \\
\hline Personalit & & & & \\
\hline No & 106 & $93(87.7)$ & 82.5-92.9 & 0.931 \\
\hline Maybe & 1 & $1(100)$ & $100.0-100.0$ & \\
\hline Yes & 17 & $15(88.2)$ & $75.3-100.0$ & \\
\hline Total & 124 & $109(87.9)$ & $83.1-92.7$ & \\
\hline Prior supe & & & & \\
\hline No & 61 & $55(90.2)$ & 83.9-96.5 & 0.621 \\
\hline Maybe & 12 & $10(83.3)$ & $65.6-100.0$ & \\
\hline Yes & 59 & $50(84.7)$ & $77.0-92.4$ & \\
\hline Total & 132 & 115 (87.1) & $82.3-91.9$ & \\
\hline Clinical scal & & & & \\
\hline Lack of in & & & & \\
\hline No & 124 & $113(91.1)$ & $86.9-95.3$ & $<0.001$ \\
\hline Maybe & 12 & $10(83.3)$ & $65.6-100.0$ & \\
\hline Yes & 38 & $23(60.5)$ & $47.5-73.5$ & \\
\hline Total & 174 & $146(83.9)$ & $79.3-88.5$ & \\
\hline Negative & & & & \\
\hline No & 142 & 127 (89.4) & $85.2-93.6$ & 0.001 \\
\hline Maybe & 9 & $9(100)$ & $100.0-100.0$ & \\
\hline Yes & 21 & $13(61.9)$ & $44.5-79.3$ & \\
\hline Total & 172 & $149(86.6)$ & $82.4-90.9$ & \\
\hline Active syr & & & & \\
\hline No & 143 & $133(91.1)$ & $87.2-95.0$ & $<0.001$ \\
\hline Maybe & 13 & 12 (92.3) & $80.1-100.0$ & \\
\hline Yes & 27 & $14(51.9)$ & $36.1-67.7$ & \\
\hline Total & 183 & $159(86.9)$ & $82.8-91.0$ & \\
\hline
\end{tabular}


Table 4 (Continued)

\begin{tabular}{|c|c|c|c|c|}
\hline \multirow[b]{2}{*}{ Variables } & \multirow[b]{2}{*}{ Total } & \multicolumn{2}{|c|}{ Dangerousness cessation } & \multirow[b]{2}{*}{$\mathrm{p}$-value } \\
\hline & & $\mathrm{n}(\%)$ & $95 \% \mathrm{Cl}$ & \\
\hline \multicolumn{5}{|l|}{ Impulsivity } \\
\hline No & 94 & $84(89.4)$ & $84.2-94.6$ & \multirow[t]{4}{*}{$<0.001$} \\
\hline Maybe & 7 & $2(28.6)$ & $0.5-56.7$ & \\
\hline Yes & 6 & $4(66.7)$ & $35.0-98.4$ & \\
\hline Total & 107 & $90(84.1)$ & 78.3-89.9 & \\
\hline \multicolumn{5}{|c|}{ Unresponsive to treatment } \\
\hline No & 142 & $134(94.4)$ & $91.2-97.6$ & \multirow[t]{4}{*}{$<0.001$} \\
\hline Maybe & 16 & $11(68.8)$ & 49.7-87.9 & \\
\hline Yes & 15 & $6(40)$ & $19.2-60.8$ & \\
\hline Total & 173 & $151(87.3)$ & 83.1-91.4 & \\
\hline \multicolumn{5}{|c|}{ Risk management scale } \\
\hline \multicolumn{5}{|c|}{ Plans lack feasibility } \\
\hline No & 132 & 117 (88.6) & 84.0-93.2 & \multirow[t]{4}{*}{0.002} \\
\hline Maybe & 5 & $3(60)$ & $24.0-96.0$ & \\
\hline Yes & 5 & $2(40)$ & $4.0-76.0$ & \\
\hline Total & 142 & $122(85.9)$ & $81.1-90.7$ & \\
\hline \multicolumn{5}{|c|}{ Exposure to destabilizers } \\
\hline No & 86 & $80(93)$ & $88.5-97.5$ & \multirow[t]{4}{*}{0.042} \\
\hline Maybe & 19 & 15 (78.9) & $63.5-94.3$ & \\
\hline Yes & 21 & $16(76.2)$ & $60.9-91.5$ & \\
\hline Total & 126 & $111(88.1)$ & 83.3-92.8 & \\
\hline \multicolumn{5}{|c|}{ Lack of personal support } \\
\hline No & 131 & $119(90.8)$ & $86.6-95.0$ & \multirow[t]{4}{*}{0.01} \\
\hline Maybe & 18 & 13 (72.2) & $54.8-89.6$ & \\
\hline Yes & 26 & $19(73.1)$ & $58.8-87.4$ & \\
\hline Total & 175 & $151(86.3)$ & $82.0-90.6$ & \\
\hline \multicolumn{5}{|c|}{ Noncompliance with remediation attempts } \\
\hline No & 123 & $105(85.4)$ & $80.2-90.6$ & \multirow[t]{4}{*}{0.878} \\
\hline Maybe & 18 & 16 (88.9) & $76.7-100.0$ & \\
\hline Yes & 33 & 29 (87.9) & $78.6-97.2$ & \\
\hline Total & 174 & $150(86.2)$ & $81.9-90.5$ & \\
\hline \multicolumn{5}{|l|}{ Stress } \\
\hline No & 81 & $73(90.1)$ & $84.6-95.6$ & \multirow[t]{4}{*}{$<0.001$} \\
\hline Maybe & 6 & $4(66.7)$ & $35.0-98.4$ & \\
\hline Yes & 6 & $2(33.3)$ & $1.6-65.0$ & \\
\hline Total & 93 & 79 (84.9) & 78.8-91.0 & \\
\hline
\end{tabular}

$95 \% \mathrm{Cl}=95 \%$ confidence interval.

of dangerousness and risk of violence. The marked differences in the criteria adopted by forensic psychiatry systems in different countries attests to the complexity of systematizing this field, as described by AbdallaFilho. ${ }^{35,36}$

Regardless of technical and scientific difficulties, ethical dilemmas, and "technical errors," expert assessments of dangerousness are currently required by the Brazilian legal system - and thus they should and must be studied and improved in order to ensure protection to the public and the individual.

The 1984 revision of the Penal Code was based on the work of forensic psychiatrist Heitor Carrilho, produced in the 1940s. This means that many scientific and technological advances in medicine were left out. Diagnosis, treatment, and prognosis in psychiatry have undergone important changes over the past decades, and it is currently unacceptable to perpetuate the notion that dangerousness is inherent to mental illness. There is solid evidence in scientific studies, including systematic reviews and meta-analyses, that proves that mental illness is far from being the most important factor in assessing risk of violence, and may not even be an isolated factor. ${ }^{1,20,21,28,30,33,34,37}$
Bonta et al. ${ }^{30}$ conducted a meta-analysis to evaluate the main predictors of criminal recidivism in individuals with and without mental illness. A total of 64 studies with 74 predictors were analyzed. Individuals with serious mental illness, such as psychosis, were less likely than the overall population to recidivate with violent or nonviolent crimes. The investigators found that the chief predictors were a criminal background in adult life, a background of delinquency during adolescence, substance abuse, antisocial personality disorder, and familial maladjustment.

Menezes ${ }^{21}$ found that the association between violence and mental illness was weak. In that study, the most important findings had to do with the lack of psychiatric treatment before the offense, and concurred with previous works in that offenses under these conditions are avoidable.

In a review of the literature, Valença \& Moraes ${ }^{33}$ sought evidence of a correlation between mental disorders and homicide. According to that study, the risk is only increased when there is concomitant personality disorder, substance abuse, and/or noncompliance with treatment.

Alden et al. ${ }^{37}$ followed up a cohort of 358,118 live births from 1944 through 1947 and collected data on convictions 
for sexual offenses, with or without violence, 50 years later, considering the presence of one of the following three: mental illness, substance abuse, or personality disorders. In psychotic individuals, whether schizophrenic or not, an association was found with higher-than-average risk only when there was co-morbidity with personality disorders or substance abuse. As an isolated variable, psychosis did not entail increase in risk. Another interesting finding of that work was the correlation between violence and organic brain disorders. Other studies report difficulty in managing these patients, ${ }^{38,39}$ and the topic deserves further investigation . In our work, the diagnoses of personality disorder were factored into the analysis whenever they were present in the reports. The fact that the percentage encountered was lower than expected may reflect a difficulty in establishing or describing such a diagnosis, or it may reveal that most of the experts did not attribute great importance to that diagnosis. Indeed, the numbers are far lower than those found by Alden et al. ${ }^{37}$ and others. ${ }^{20,22,30}$

Fazel \& Rongquin, ${ }^{28}$ in a meta-analysis of 27 studies, compared the risk of criminal recidivism among a total 3,511 psychotic individuals, 5,446 with mental illness but not psychotic, and 71,552 with no mental illness. They found a significant risk ratio of 1.6 for recidivism in psychotic individuals as compared to healthy individuals, but that comparison was found in only four of the studies. Moreover, none of those four studies covered the issue of co-morbidity with substance abuse and personality disorders, which was shown to significantly increase the risk of dangerousness in the studies that did take that into account. In the comparison between psychotic and other mentally disordered individuals, the odds ratio was 1.0 , with no statistical significance.

One must take into account that samples are heterogeneous, and also that, ceteris paribus, it is more likely for a psychotic individual to be caught, given the disorganization and the greater chance of not being fully aware of the consequences of an unlawful action. In our study we came across several cases of schizophrenia, and most of these individuals had received positive dangerous cessation reports.

Valença et al. ${ }^{34}$ studied the psychological profile of sexual offenders in the city of Rio de Janeiro, analyzing 44 expert reports. The predominant profile was male Caucasians with part-time employment and no mental illness.

The mentally disordered are no more dangerous than anybody else, according to the studies we have analyzed, albeit they may be more dangerous under very particular circumstances. Even so, it is prejudiced and contrary to scientific evidence to consider them a higher risk group than the general population. Offenses committed by persons with mental illness usually involve lack of treatment and/or medication, which can lead to diminished or no awareness of the illicit nature of a given action. This is the rationale underlying the sparing by the Brazilian Penal Code of individuals with mental illness who have been considered unchargeable from serving sentences of a punitive nature, which are replaced with involuntary commitments.
According to studies by Valença et al. ${ }^{22,33,40}$ on mental illness in a forensic context, crimes can be avoided by correctly identifying mental disorders and by adequately treating them. What we see is that effective actions to improve diagnosis and treatment are an important part of crime prevention strategies. Since factors that can be controlled or avoided play a significant role in reducing criminal recidivism, it can be argued that providing adequate treatment and consequently improving the chances of reinsertion into the community will diminish risk to the individual and to society. ${ }^{1,19,22,40,41}$

The interpretation of our data was hindered to a large degree by the lack of systematized and standardized data collection mostly due to the scarcity of relevant information in the reports, which turned out to be insufficient for proper statistical analysis. We recommend using validated instruments to develop a semi-structured interview for the purpose of assessing the risk for violence in forensic settings. This would probably produce sound data with which solid associations could be established in further studies.

A reorganization of the official evaluation system and specific training for forensics experts carrying out such assessments, highlighting greater awareness of the importance of a thorough annotation of the psychiatric examination, would improve the quality of the reports. Centralized and readily accessible medical information would also be useful, both in clinical practice and in studies that rely on statistical analyses.

We believe that our work may contribute to the study of dangerousness cessation in individuals subjected to the safety measure. This subject is undoubtedly one that warrants further research with studies involving larger numbers of patients and using more specific methodology, such as standardized questionnaires for the examiners.

In conclusion, the present study identified factors that have a correlation with dangerousness according to expert reports. Identifying factors for risk of recidivism in unlawful activities or violent behavior is crucial to for decision-making regarding the release of individuals with mental illness who have been involuntarily committed.

\section{Disclosure}

The authors report no conflicts of interest.

\section{References}

1 Mecler K. Periculosidade: evolução e aplicação do conceito. Rev Bras Crescimento Desenvolv Hum. 2010;20:70-82.

2 Mecler K. Periculosidade e inimputabilidade: um estudo dos fatores envolvidos na determinação da periculosidade do doente mental infrator [dissertation]. Rio de Janeiro: Universidade Federal do Rio de Janeiro; 1996.

3 Carrara S. Crime e loucura: O aparecimento do manicômio judiciário na passagem do século. Rio de Janeiro: EdUERJ; 1998.

4 Bruno A. Perigosidade criminal e medidas de segurança. Rio de Janeiro: Editora Rio; 1977.

5 Loudet $\mathrm{O}$. Los índices médico-psicológicos y legales de la peligrosidad. Actos, delibefaciones y trabajos del Premier Congreso Latino-Americano de Criminologia, Buenos Aires; 1939. p. 175-83. 
6 Carrilho H. A colaboração dos psiquiatras nas questões penais. Arq Manicomio Judic R Janeiro. 1930;1:159-82.

7 Carrilho $H$. Psicogênese e determinação pericial da Periculosidade. Arq Manicomio Judic R Janeiro. 1941;3:56-89.

8 Delmanto C. Código penal comentado. Rio de Janeiro: Renovar; 1981.

9 Morais TM. Ética e psiquiatria forense. Rio de Janeiro: IPUB-CUCA 2001.

10 Hare RD. Hare Psychopathy Checklist-revised (PCL-R): technical manual. 2nd ed. Toronto: Multi-Health Systems; 2007.

11 Barrat ES. Impulsiveness and aggression. In: Monahan J, Steadman HJ. Violence and mental disorder. Chicago: University of Chicago Press; 1994. p. 61-5.

12 Webster CD, Eaves D, Douglas KS, Winthrop A. The HCR-20 scheme: the assessment of dangerousness and risk - version 1. Burnaby: Simon Fraser University and Forensic Psychiatric Services Commission of British Columbia; 1995.

13 IBM. SPSS Statistics [Internet] v.20. 2013. www-01.ibm.com/software/analytics/spss/products/statistics/

14 Vieira SBioestatística: tópicos avançados. $3^{\mathrm{a}}$ ed. Rio de Janeiro: Elsevier; 2010.

15 Bruni AL. SPSS aplicado è pesquisa acadêmica. São Paulo: Atlas; 2009.

16 Abdalla-Filho E, Souza PA. Bioética, psiquiatria forense e a aplicação da medida de segurança no Brasil. Rev Bioet. 2009;17:181-90.

17 Abdalla-Filho E. Avaliação de risco. In Taborda JGV, Chalub M, AbdallaFilho EPsiquiatria forense.Porto Alegre: Artmed; 2012. p.183-201.

18 Filho EA, Garrafa V. Psychiatric examination on handcuffed convicts in Brazil: ethical concerns. Dev World Bioeth. 2002;2:28-37.

19 Abdalla-Filho E. Objectivity and subjectivity in forensic psychiatry Rev Bras Psiquiatr. 2013;35:113-4.

20 Whittington R, Hockenhull JC, McGuire J, Leitner M, Barr W, Cherry $M G$, et al. A systematic review of risk assessment strategies for populations at high risk of engaging in violent behaviour: update 2002-8. Heath Technol Assess. 2013;17:i-xiv, 1-128.

21 Menezes RS. Homicídio e esquizofrenia: estudo de fatores associados [dissertation]. Porto Alegre: Universidade Federal do Rio Grande do Sul; 2001.

22 Valença AM, Nascimento I, Nardi AE. Relationship between sexual offenses and mental and developmental disorders: a review. Rev Psiq Clin. 2013;40:97-104

23 Telles LEB, Folino JO, Taborda JGV. Incidência de conduta violenta e antissocial em população psiquiátrica forense. Rev Psiquiatr Rio Gd Sul. 2011;33:3-7.

24 Lopes RMF, Mello DC, Argimon IIL. Mulheres encarceradas e fatores associados a drogas e crimes. Cienc Cogn. 2010;15:121-31.
25 Telles LEB. Perícias de responsabilidade penal realizadas no Instituto Psiquiátrico Forense. Rev Multijuris. 2007;2:44-9.

26 Ghoreishi A, Kabootvand S, Zanganib E, Bazargan-Hejazi S, Ahmadi $\mathrm{A}$, Khazaie $\mathrm{H}$. Prevalence and attributes of criminality in patients with schizophrenia. J Inj Violence Res. 2015;7:7-12.

27 Achá MFF, Rigonatti SP, Saffi F, Barros DM, Serafim AP. Prevalence of mental disorders among sexual offenders and non-sexual offenders. J Bras Psiquiatr. 2011;60:11-5.

28 Fazel S, Yu R. Psychotic disorders and repeat offending: systematic review and meta-analysis. Schizophr Bull. 2011;37:800-10.

29 Moscatello R. Recidiva criminal em 100 internos do Manicômio Judiciário de Franco da Rocha. Rev Bras Psiquiatr. 2001;23:34-5.

30 Bonta J, Law M, Hanson K. The prediction of criminal and violent recidivism among mentally disordered offenders: a meta-analysis. Psychol Bull. 1998;123:123-42.

31 Abdalla-Filho E. Avaliação de risco de violência em Psiquiatria Forense. Rev Psiquiatr Clin. 2004;31:279-84.

32 Telles EB, Day VP, Folino JO, Taborda JG. Reliability of the Brazilian version of HCR-20 assessing risk for violence. Rev Bras Psiquiatr. 2009;31:253-6.

33 Valença AM, de Moraes TM. [Relationship between homicide and mental disorders]. Rev Bras Psiquiatr. 2006;28:S62-8.

34 Valença AM, Meyer LF, Freire F, Mendlowicz MV, Nardi AE. A forensic-psychiatric study of sexual offenders in Rio de Janeiro, Brazil. J Forensic Leg Med. 2015;31:23-8.

35 Abdalla-Filho E. Bertolote JM. [Forensic psychiatric systems in the world]. Rev Bras Psiquiatr. 2006;28:S56-61.

36 Abdalla-Filho E, Engelhardtb W. [The practice of forensic psychiatry in England and Brazil: a brief comparison]. Rev Bras Psiquiatr. 2003;25:245-8.

37 Alden A, Brennan P, Hodgins S, Mednick S. Psychotic disorders and sex offending in a Danish birth cohort. Arch Gen Psychiatry. 2007;64:1251-8.

38 Oliveira GC, Madeira MC, Celmer MD. Alterações de comportamento na encefalite herpética: um caso polimórfico e de difícil manejo. J Bras Psiquiatr. 2015;64:307-10.

39 Monteiro VL, Barreto FJ, Rocha PM, do Prado PH, Garcia FD, Correa $\mathrm{H}$, et al. Managing severe behavioral symptoms of a patient with antiNMDAR encephalitis: case report and findings in current literature. Trends Psychiatry Psychother. 2015;37:47-50.

40 Valença AM, Mendlowicz MV, Nascimento I, Moraes TM. Mental retardation: dangerousness and penal responsibility. J Bras Psiquiatr. 2011;60:144-7

41 Abdalla-Filho E, De Souza PA, Tramontina JF, Taborda JG. Mental disorders in prisons. Curr Opin Psychiatry. 2010;23:463-6. 